\title{
The Western Amazonia Igneous Belt
}

\author{
Gilmar José Rizzotto ${ }^{\mathrm{a}, *}$, Cléber Ladeira Alves ${ }^{\mathrm{a}}$, Francisco Sene Rios ${ }^{\mathrm{a}}$, \\ Márcia Aparecida de Sant'Ana Barros ${ }^{\mathrm{b}}$ \\ ${ }^{a}$ Geological Survey of Brazil (CPRM), Rua 148, $n^{\circ}$ 485, 74170-110, Goiânia, Goiás, Brazil \\ ${ }^{\mathrm{b}}$ Institute of Geosciences of the Federal University of Mato Grosso, Rua 44, No. 41, CEP 78.068-505, Cuiabá, Mato Grosso, Brazil
}

\section{A R T I C L E I N F O}

\section{Keywords:}

Amazonian craton

Bimodal magmatism

Underplating

Teles pires suite

\begin{abstract}
A B S T R A C T
The Western Amazonia Igneous Belt (WAIB) occupies the northern part of South American continent, and a total area close to $125,000 \mathrm{~km}^{2}$. The belt is composed dominantly by volcano-plutonic felsic rocks (Juruena supersuite, Teles Pires suite and Colíder group) and has dominant alkali-calcic, metaluminous to peraluminous, ferrous, geochemical characteristics, similar to A-type granites. The Silicic members are represented by granites and rhyolitic-rhyodacitic volcanic rocks, mafic members by gabbroic rocks and diabase dykes. Intermediate rocks are rare. Local magma mingling and hybridization are present in several areas. The assemblage of silicic and basic rocks of WAIB was formed between c. 1825 and $1757 \mathrm{Ma}$. The presence of inherited zircons, from 1875 to $2050 \mathrm{Ma}$, as well as some Archean ages in the granitic and volcanic rocks from the WAIB, are suggestive of derivation by melting of pre-existing crustal basement (Ventuari-Tapajós Province). This hypothesis is also corroborated by bimodal magmatism and by several model-ages of granites, felsic volcanic rocks and mafic plutonic rocks, with $\mathrm{T}_{\mathrm{DM}}$ ranging from 2.0 to $2.3 \mathrm{Ga}$, and $\varepsilon_{\mathrm{Nd}}$ value, varying from -3.90 to +2.52 .

The preferred model of formation of the WAIB envisages the emplacement of large volumes of hot mantlederived melts into the lower crust. These processes resulted in partial melting of lower-crustal material, mixing with the mantle-derived melts and formation of granitic melts. The timing and spatial features and interpreted petrogenetic mechanisms of WAIB are suggestive of a continental rift setting. In addition, this volcano-plutonic province is similar to silicic igneous provinces (Silicic Large Igneous Province-SLIP) in areal extent, eruptive volume and petrogenetic characteristics.
\end{abstract}

\section{Introduction}

The Amazonian craton covers the largest Archean-Proterozoic continental area of the South American continent, and is divided into two exposed parts: Guiana shield in the north, and Central Brazil shield in the south (Fig. 1). Similarly, the Amazonian craton was subdivided into two Archean nuclei and five Proterozoic tectonic provinces, showing internally coherent structural and age patterns (Tassinari and Macambira, 1999) (Fig. 1). The craton was formed mainly by Paleoproterozoic orogenic collages of Archean cratonic nuclei during the Transamazonian Orogeny $(2.2-2.0 \mathrm{Ga})$ in its eastern portion, while younger (Mesoproterozoic) accretionary events occurred in the western portion. Therefore, such fusion processes were essential in origin this immense tectonic block. On the other hand, global taphrogenesis took place on the Paleoproterozoic terranes of South American platform, from the late Orosirian to the Statherian (e.g. Araí Rift; Botelho and Moura, 1998). In the initial phase of continental extension, dyke swarms were associated with fracturing, and magma injection led to melting of lower continental crust and further anorogenic magmatism. Voluminous volcanic and plutonic anorogenic activity was in several cases associated with mantle diapirism or mantle super swells under a Paleoproterozoic supercontinent (Storey et al., 2001; Turcotte and Schubert, 2002), generating large belts of igneous rocks by additions of magma to the continental crust both at the surface and at depth, similar to Large Igneous Provinces (LIPs).

In this context, we presently characterize and define the Western Amazonia Igneous Belt (WAIB), occupying the northern part of the South American continent, with a total area close to $125,000 \mathrm{~km}^{2}$ (Fig. 2). Extensive igneous activity in the WAIB in Statherian time, and during the Calymmian occurred in the western corner of the belt. Massive quantities of high-K granitic magma were produced in this belt.

Despite lack of convincing evidence, these igneous rocks were interpreted as a continental arc (e.g., Santos et al., 2000; Souza et al., 2005; Scandolara et al., 2014, 2017; Duarte et al., 2012; Assis, 2015). In recent years, however, mafic dyke swarms and mafic intrusions associated with subvolcanic and shallow intrusive A-type granitoids, and

\footnotetext{
* Corresponding author.

E-mail address: grgilmarjose@gmail.com (G.J. Rizzotto).
} 


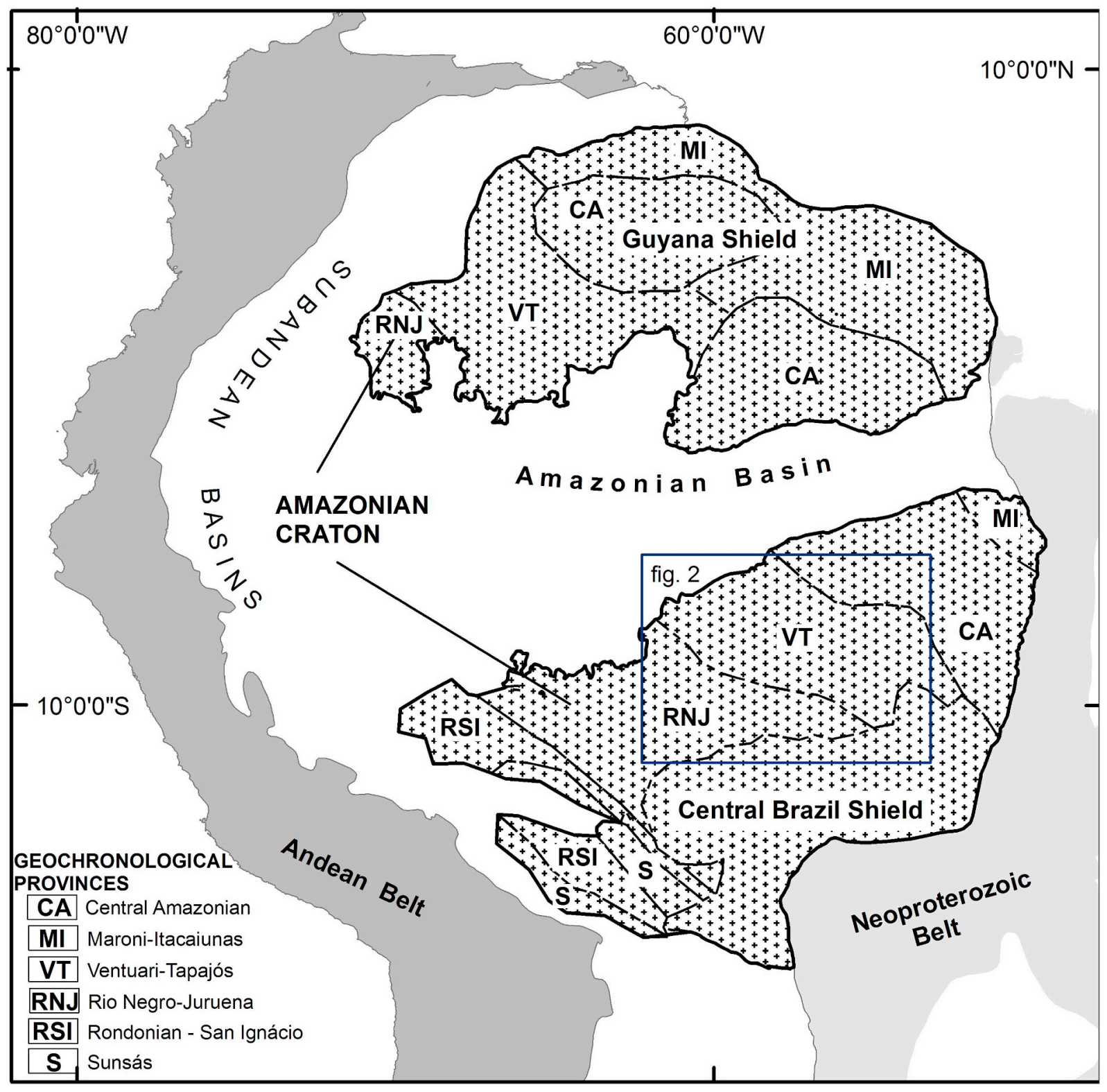

Fig. 1. Schematic map of the Amazonian craton with the location of the studied area (Fig. 2) and division into geochronological provinces.

coeval felsic volcanic rocks were found in the WAIB (Neder et al., 2002; Rizzotto et al., 2019).

Felsic volcanic and volcaniclastic rocks (rhyolite, trachyte, minor dacite, and ignimbrite) and A-types granite are the most common lithological assemblages in extensional tectonic settings, together with minor mafic dyke swarms and mafic intrusions (Bonin, 2007; Frost and Frost, 2008). Associated magmatism varies from alkaline to subalkaline, and bimodal suites are typical of most continental rift environments. In this way, rhyolitic volcanoes (volcanic domes) and A-type granitic batholiths are the major manifestations of silicic magmatism, and are important igneous building blocks of continents.

From a geodynamic perspective, intraplate bimodal magmatism was suggested to be related to thermal perturbations in the upper mantle with associated mafic underplating of plume-like character, or a result of crustal extension decompression and mantle upwelling (Aitken et al., 2013; Pirajno and Santosh, 2015). The model including magmatic underplating and crustal anatexis in an extensional tectonic environment was first applied to Finnish rapakivi granites by Haapala (1985), Haapala and Rämö (1999) and Nurmi and Haapala (1986). The associated mafic magmatism was directly mantle-derived, as assumed for intraplate bimodal magmatic suites (Dall'Agnol and Oliveira, 2007). In the same way, Paleoproterozoic A-type granites were described from many Precambrian shield areas, e.g., South America (Dall'Agnol et al., 1994, 2005), Fennoscandia (Haapala and Rämö, 1999; Ahl et al., 1997), North America (Anderson, 1983; Anderson and Bender, 1989; Emslie, 1991; Barnes et al., 1999). Typically, these granites are found as discordant multiple plutons, show bimodal (mafic-felsic) magmatic association, include rock types with rapakivi texture, and were intruded into an igneous and metamorphic crust that predated them by some hundred million years (e.g., Dall'Agnol et al., 2005; Rämö and Haapala, 1995). In Central Brazil shield, more specifically in the southern part of the Rio Negro-Juruena Province, a major period of felsic volcanism and granite emplacement with these same characteristics occurred between 1820 and $1760 \mathrm{Ma}$. In a similar geological context, voluminous intraplate mafic activity in the northern part of the Amazonian craton (Guiana Shield) is represented by Avanavero (1.79 Ga) LIP event of mafic dykes and sills (Reis et al., 2013). In this context, the Juruena supersuite, Teles Pires suite and Colíder group have similar ages to Avanavero LIP, and formed by breakup attempt of the continental lithosphere due to mantle convection reorganization below the already 


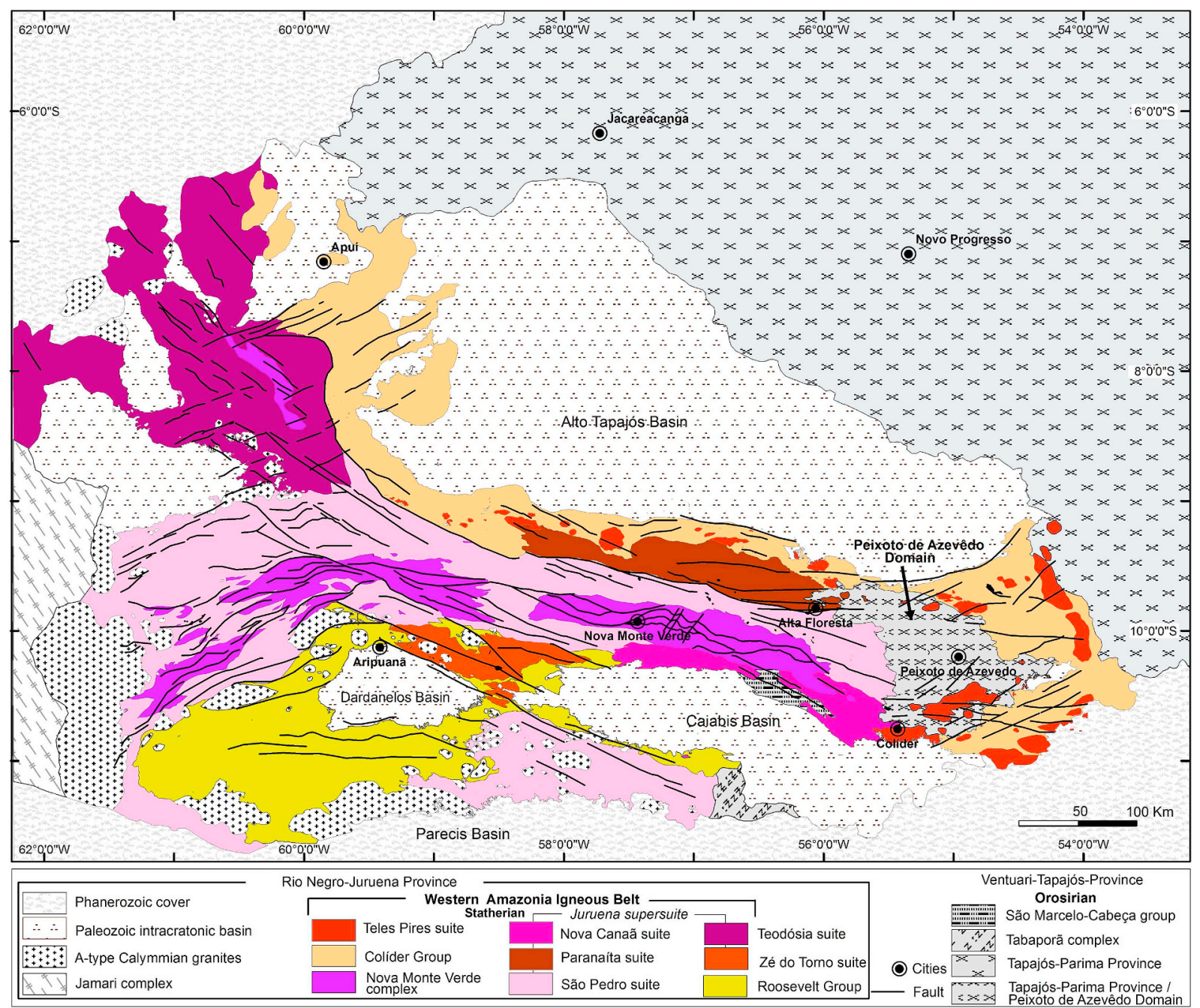

Fig. 2. Simplified geological map of SW Amazonian Craton, showing the Western Amazonia Igneous Belt and the oldest terrains: Ventuari-Tapajós Province (Peixoto de Azevêdo Domain).

stable Paleoproterozoic/(Archean) continental lithosphere.

The tectonic environment in which the rocks of the Rio NegroJuruena Province were formed remains a major problem in Precambrian geology of Amazonian craton. For this reason, there are many contrasting suggestions of possible origin, such as: a) magmatism derived from the evolution of continental magmatic arc (e.g., Santos et al., 2000; Souza et al., 2005; Scandolara et al., 2014, 2017; Duarte et al., 2012; Assis, 2015), and b) bimodal magmatism generated in an intraplate extensional environment (Pinho et al., 2001; Neder et al., 2002; Rizzotto and Quadros, 2005; Leite et al., 2005; Barros et al., 2009; Rizzotto et al., 2016).

In light of this paradox in paleoenvironmental interpretations we reevaluate the origin of Statherian bimodal magmatism of the WAIB in the southern part of Rio Negro-Juruena Province (RNJP). We present new data from geological mapping, geophysical interpretation (magnetometry, gamma spectrometry, and gravity data), associated with petrographic, geochemical and geochronological studies. We suggest a new interpretation regarding the evolution of this expressive acid magmatism, and present a new geotectonic conception for the southwestern Amazonian craton.

\section{Regional geological context}

The WAIB consists of a set of massifs of granitic and volcanic rocks and associated mafic intrusions $(1.82-1.76 \mathrm{Ga})$. This belt of magmatic rocks is $820 \mathrm{Km}$ long and $150 \mathrm{Km}$ wide, and borders a core of highgrade metamorphic rocks (Nova Monte Verde Complex, 1.80-1.76 Ga) (Fig. 2). A remnant core of older rocks to the east of this belt is named Peixoto de Azevedo Domain (2.80-1.87 Ga) and represents a remaining cratonic block of the Ventuari-Tapajós Province (VTP), that is the continuation of VTP to the south of Alto Tapajós Basin (Fig. 2). The rocks that form the basement of this domain are inserted into the CuiúCuiú Complex (2.05-1.99 Ga), which consists of tonalitic-granodioritic gneisses, commonly migmatized, with subordinate amphibolite. A set of granitoids and associated mafic plutonic rocks was intruded into the gneisses of the complex, and constitutes an expanded calc-alkaline magmatic series derived from the continental magmatic arc (Pé Quente suite, Guarantã suite; Assis, 2015). Another group of granitoids with similar genesis to the granitoids in the complex known as Novo Mundo, Aragão, Nhandu and Flor da Mata (Paes de Barros, 2007; Assis, 2015), was grouped into the Nhandu Intrusive suite. These granitoids have similar structural, textural, chemical and isotopic characteristics, in addition to zircon U-Pb ages between 1970 and $1955 \mathrm{Ma}$, correlated with Creporizão intrusive suite of Tapajós (VTP). Other group of younger granitoids is predominant in the southern part of the VTP, included in the Matupá intrusive suite (1890-1870 Ma) and has chemical characteristics compatible with formation in an intraplate extensional environment correlated to the Parauari and Maloquinha intrusive suite of Tapajós. This entire set of basement rocks and granitoids 
is distributed in the Peixoto de Azevêdo Domain, and has $\mathrm{T}_{\mathrm{DM}}$ ages $>$ $2.30 \mathrm{Ga}$ and $\mathrm{U}-\mathrm{Pb}$ crystallization ages ranging from 2.1 to $1.87 \mathrm{Ga}$, except for a few outcrops of gneiss-migmatitic rocks from the Gavião Gneiss Unit (Paes de Barros, 2007) dated at $\sim 2.8 \mathrm{Ga}$ (Archean). After $1.95 \mathrm{Ga}$, the Peixoto de Azevêdo Domain developed as a stable platform; deformational events and high-grade metamorphism were not observed.

On the other hand, the Western Amazonia Igneous Belt (WAIB) has granitoid rocks that show different degrees of deformation and metamorphism, ranging from multi-deformed rocks to rocks with incipient foliation or isotropic. In this context, the Nova Monte Verde Complex is represented by a strip of granulitic-migmatitic gneissic rocks. In previous studies, migmatite-gneiss domes were considered an old basement and were included in the Xingu Complex, with Archean/ Paleoproterozoic age (Silva et al., 1974; Japan International Cooperation Agency, 2001). Associated with this "basement", the granitic masses were considered the product of remobilization of a migmatite-gneiss basement, and named Juruena Granite, which includes tonalite, granodiorite, quartz-monzodiorite, quartz-diorite and quartz-syenite. We presently name this stratigraphic unit as Juruena supersuite.

Granitic bodies included in the Juruena supersuite are batholiths and stocks, elongated through the EW structure, bordering this belt of migmatitic and granulitic rocks, and are found both in the north and south of Nova Monte Verde Complex. These bodies have augen-gneiss texture, and farther from the metamorphic core deformation becomes weaker, showing rocks with incipient igneous flow fabric to isotropic. Isotropic rocks have transitional contacts with acid subvolcanic and volcanic predominantly explosive intrusions. In places, interdigitation between explosive volcanic and volcano-sedimentary rocks from the Colíder and Roosevelt groups is observed. These units have texture produced by low-grade metamorphism and are predominantly nonmetamorphosed.

Souza et al. (2005) called the deformed to isotropic granitic and granodioritic rocks of "Juruena intrusive suite" and defined other units as Nhandu Granite, São Pedro Granite, São Romão Granite, Apiacás Granite and Nova Canaã suite. Among the units defined by Souza et al. (2005), the crystallization age of $1.96-1.97 \mathrm{Ga}$ of the Nhandú Granite led to repositioning it stratigraphically (Barros et al., 2015). On the other hand, petrographic, geochemical and isotopic similarities, together with field characteristics of São Pedro, São Romão, Apiacás and Nova Canaã units, made possible to group them into one unit called "Juruena supersuite". This significant plutonic felsic magmatism and associated acid volcanic rocks are widely distributed in an area of approximately $270,000 \mathrm{~km}^{2}$ bordering the high-grade metamorphosed complex (Fig. 2). This acid magmatism occurs in the SW border of the VTP. The basement south of RNJP is constituted by fragments or "islands" of gneiss rocks, metavolcanic-sedimentary units and granitoids. Ages are older than WAIB, cropping out in a small and isolated dispersed nucleus, predominantly at the margins of the Alto Tapajós and Caiabis basins. Rocks of the basement are represented by the Jacareacanga group, São Marcelo-Cabeça group, Tabaporã Complex and several granitoids older than $1.8 \mathrm{Ga}$.

The Juruena supersuite granitoids have transitional contacts. Regarding their composition, no significant variations were observed among granites of Juruena supersuite, except for the Apiacás granite which is more peraluminous. However, the differences in texture of the granites of the supersuite are distinct, showing different intensities of metamorphism and deformation. Therefore, the Juruena supersuite is formed by granites that vary from isotropic to those with igneous flow foliation, weakly foliated, to metagranites with penetrative foliation, grading to augen gneisses. Among them, monzogranites predominate, with subordinate granodiorites. Mixing features of different magmas are also characteristic of these lithotypes, which show microgranular enclaves of composition ranging from basic to intermediate, and biotite cluster (melting restites), in addition to rapakivi texture. Fig. 2 shows the distribution of the Juruena supersuite and division into suites.

The acid volcanic rocks belong to the Colíder group, considered the volcanic equivalent of the Juruena supersuite and Teles Pires suite plutonism. This group is mainly formed by pyroclastic and effusive volcanic rocks, with predominantly rhyolitic-dacitic composition, with subordinate andesitic basalts and andesites. The plutonic and subvolcanic intrusives of the Teles Pires suite, with textural and structural features of epizone, in addition to features of magma mixing, form together with the volcanic rocks of the Colíder group a co-magmatic set.

The mafic component of this extensive magmatism "Juruena-Teles Pires" is predominantly represented by mafic rocks of the Vespor Mafic suite, mainly distributed in the interfluves of Juruena and Roosevelt rivers. This lithostratigraphic unit consists of metagabbros, amphibolites, mafic granulites and metadiorites genetically associated in time and space with migmatites and granulites of the Nova Monte Verde Complex. Moreover, a swarm of diabase dykes and small gabbro bodies, either metamorphosed or not, included in the Guadalupe Intrusive suite, are probably coeval with mafic rocks of the Vespor suite, and crop out on the interfluve between Juruena and Teles Pires rivers.

\subsection{Morphology, stratigraphy and petrography of main types of rocks}

\subsubsection{Juruena supersuite}

Acid magmatism of Juruena supersuite is widespread along a continuous WNW-ESE belt approximately $1200 \times 300 \mathrm{~km}$, in the centreeast of Rio Negro-Juruena Province and is represented by a series of granitic bodies and, to a lesser extent, by granodiorites, with crystallization ages ranging from 1810 to $1770 \mathrm{Ma}$ (Rizzotto and Quadros, 2005). In general, granitic masses (batholiths and stocks) are aligned in the EW direction (Fig. 2), with the same trend of the metamorphic core complex (Nova Monte Verde Complex), with ellipsoidal bodies showing magmatic foliation and, more rarely, mylonitic structure with elongation of megacrysts of K-feldspar and quartz, and alignment of biotite clusters. Mylonites derived from granites are restricted to narrow transcurrent zones with EW direction, in many places associated with brecciation developed in shallower levels of the crust.

One of the granitic massifs peculiarities is their variable deformational style. Granites that are in contact, both in the north and south, with the migmatite-gneiss rocks of the Nova Monte Verde Complex, show magmatic flow foliation sub-concordant to the foliation developed during the subsolidus stage, often showing augen structure. Moving away from the contact zone with high-grade metamorphic rocks, granites show only an incipient foliation marked by the alignment of biotites and euhedral K-feldspar crystals, where only quartz is elongated. Moving away from the metamorphic core complex toward north, where the granites are in contact with volcanic rocks of Colíder group (Fig. 2), these intrusives are mainly isotropic, with rare features of magmatic flow, shown by the alignment of prismatic K-feldspar crystals and incipient mylonitic fabric in restricted and narrow zones, with predominance of brittle features (cataclasite, breccia, quartz vein in dilatation zone).

According to field characteristics, in addition to textural, compositional and structural characteristics, the Juruena supersuite is divided into the following suites: São Pedro, Paranaíta and Nova Canaã (see description in Appendix A).

\subsubsection{Colíder group}

This unit consists predominantly of acid volcanic rocks (lava, lava dome, and pyroclastic rocks) and epiclastic rocks. The unit is distributed along an elongated, continuous belt, with EW to WNW direction, and borders the southern part of Alto Tapajós Basin, inflecting to the NW on the interfluve between Aripuanã and Sucundurí rivers. To the east, the unit partially overlies rocks of Peixoto de Azevêdo Domain (Fig. 2) and, to the south, forms a fringe surrounding the Caiabis graben, in continuation with the volcanic rocks of the Roosevelt group. Volcanic activity represented by the rocks of the Colíder group occurred 
between 1810 and $1766 \mathrm{Ma}$ (Duarte et al., 2012; Santos et al., 2019). A detailed description of the unit is in Appendix A.

\subsubsection{Teles Pires suite}

This unit consists of plutonic rocks and acid subvolcanic intrusions associated in time and space, and genetically with volcanic rocks of Colíder group. Several bodies form stocks and, more rarely, batholiths, and are predominantly elliptical with the major axis along EW and parallel to main regional lineaments. Their contacts with the effusive rocks of the Colíder group are intrusive to transitional, and they intruded into of the Peixoto de Azevêdo Domain rocks. According to literature, there is a wide range of crystallization ages, varying from the youngest age of $1757 \mathrm{Ma}$ to the oldest age of $1782 \mathrm{Ma}$ (Souza et al., 2005; Silva and Abram, 2008). In this study, an older crystallization age was obtained for a porphyry granite (1794 Ma-see section 3). Therefore, a plutonic activity of approximately $35 \mathrm{My}$, coinciding with the period of the Colíder volcanism (37 My), confirms that the acid volcanism and plutonism in the area are coeval. The peraluminous to slightly metaluminous, alkali-calcic with high-K composition of the Teles Pires granites is very similar to that of the volcanic rocks of the Colíder group and granites of the Juruena supersuite (Duarte et al., 2012). More data for this unit in Appendix A.

\subsubsection{Teodósia and Zé do Torno suites}

Granitoids of these units, with associated subvolcanic rocks, are distributed in the far northwest, bordering the Cachimbo basin, and in the southwest, bordering the Roosevelt basin (Fig. 2). Granites of both suites yielded crystallization ages between 1756 and 1758 Ma.

Granitoid outcrops of the Teodósia suite, in the form of slabs and boulders, are distributed in the interfluve of the Aripuanã, Guariba, Roosevelt, Paxiuba rivers and the upstream area of Buiuçu river. A detailed description of the unit is in Appendix A.

\subsubsection{Roosevelt group}

The rocks of this group are widely distributed in the SW of the investigated area, on the interfluve of the Juruena and Roosevelt rivers, and to the north, extending to the town of Aripuanã-MT and, to the South, bordering the Parecis Basin. The group is represented by terrigenous volcano-sedimentary rocks (Rizzotto and Quadros, 2005; Leite et al., 2005; Biondi et al., 2013) that have characteristics of subaqueous depositional environment. The group consists of upper, middle and lower sequences: The upper sequence of rhythmites has mudstone interdigitated with chert, manganiferous siltstone, banded iron formation and tuffs. The middle sequence has explosive effusive rocks represented predominantly by ignimbrites and subordinate volcaniclastic conglomerates. The lower sequence has effusive volcanic rocks represented by dacites to rhyolites intercalated with subordinate tuffs, in addition to rare basalt dykes and sills. This volcanic - sedimentary package was folded into wide antiforms and synforms with EW to WSW axes, metamorphosed in low-greenschist facies. Crystallization ages of effusive and explosive volcanic rocks are restricted to the interval between 1763 and $1740 \mathrm{Ma}$. The Roosevelt group hosts $\mathrm{Pb}-\mathrm{Zn}-\mathrm{Ag}$ mineralization in the base of metaturbidites and metarhythmites, with structures indicative of subaqueous environment (Biondi et al., 2013). A detailed description of the unit is in Appendix A.

\subsubsection{Vespor Mafic suite}

Mafic rocks of the suite crop out as stocks of gabbros, diorites and the corresponding dyke swarms. In the neighborhood of Nova Monte Verde metamorphic core complex, mafic rocks show sigmoidal shapes and are bordered by an anastomosed network of shearing zones with EW direction, where amphibolites predominate. Features of magma mixing in acid rocks are frequent, therefore coeval with granites of the Juruena supersuite. Granite contacts are usually diffuse, with mafic enclaves within the granites and mafic microgranular enclaves containing K-feldspar phenocrysts. A detailed description of the unit is in
Appendix A.

\section{Geochronology and isotope geochemistry}

$\mathrm{U}-\mathrm{Pb}$ isotopic data presented in this study were obtained from 73 samples analyzed in previous studies on the PRNJ, including samples of the Juruena supersuite (Paranaíta, São Pedro and Nova Canaã suites), Colíder group, Teles Pires suite, Roosevelt group, Vespor Mafic suite, Teodósia suite, Zé do Torno suite and Nova Monte Verde complex, and from 9 new samples analyzed in this study (Table 1-Appendix B). Data presented in Table 1 show that the significant magmatism, predominantly acid, of the southwest of the Amazonian craton, expressed by fissural/explosive volcanism and associated plutonism, developed between 1820 and $1760 \mathrm{Ma}$. Age variations upwards or downwards are restricted and associated with isotopic perturbation, recent $\mathrm{Pb}$ loss, or analytical errors. Therefore, in an interval of $60 \mathrm{Ma}$, the bimodal magmatism events (subordinate mafic magmatism) that characterize the Western Amazonia Igneous Belt cover an area of approximately $270,000 \mathrm{~km}^{2}$ in the southwest of the Amazonian Craton, and occurred during the Statherian.

\subsection{Sampling and analytical methods}

Samples were collected during geological mapping. Our sampling covers most lithologies of granites and mafic rocks of the WAIB. These samples were crushed, milled, and split into fractions for determining the whole-rock isotopic compositions, and for dating zircon. Zircon grains were separated from nine samples, using heavy liquid and magnetic separation techniques. All rocks were examined in thin section and chemically in addition to isotopic Sm-Nd data. Six samples were analyzed by SHRIMP at Curtin University of Technology in Australia, and three samples were analyzed by LA-MC-ICP-MS at Isotope Geology Laboratory of the University of Brasília in Brazil. All grains used for zircon dating were imaged with backscattered electrons at the Centre for Microscopy Characterization and Analysis at the University of Western Australia to determine their internal structure and igneous or metamorphic growth (Fig. 4). Selected information on each sample (coordinate, rock name, and stratigraphic unit) is given in Appendix B, and isotopic data are presented in Tables 2 and 3 Analytical procedures are presented in Appendix D.

\subsection{U-Pb zircon geochronology by LA-ICPMS and SHRIMP}

\subsubsection{Juruena supersuite (Paranaíta suite)}

Granitic rocks from this unit vary in texture from isotropic, coarseto very coarse-grained, to weakly foliated, medium-grained. Brittle deformation predominated, but narrow zones of ductile deformation are sometimes observed, usually along the margins of bodies oriented in EW direction. In a profile along the main body, from south to north, in the surroundings of Paranaíta town, a decrease in deformation intensity and biotite content was observed. The main population of zircons of sample API-455 (S $09^{\circ} .5512$; W $\left.57^{\circ} .4063\right)$ yielded $\mathrm{a}^{207} \mathrm{~Pb} /{ }^{206} \mathrm{~Pb}$ age of $1813 \pm 9.8 \mathrm{Ma}$, which is interpreted as the crystallization age of syenogranite. Inherited zircons yield ages ranging from Archean (2822 Ma) to Paleoproterozoic (2076, $1861 \mathrm{Ma}$ ) (Fig. 3a), indicating inheritance from gneisses and granites of the Ventuari-Tapajós and Amazônia Central provinces.

Analyzed zircons of another granite from this suite (sample TL 35; S $09^{\circ} .6408$; W $56^{\circ} .2820$ ) display a euhedral prismatic shape, $100-300 \mu \mathrm{m}$ long, and show igneous zoning, with few inclusions and fractures. Backscattered electron images (BSE) reveal that most zircons have finescale oscillatory zoning. $\mathrm{Th} / \mathrm{U}$ ratios vary between 0.30 and 0.89 , which is suggestive of magmatic origin. Despite their euhedral shape, some imaged zircons possess anhedral cores (Fig. 4) or internal surfaces that truncate and embay into growth zones. They have euhedral forms, with internal structures with dark gray cores surrounded by light-gray 


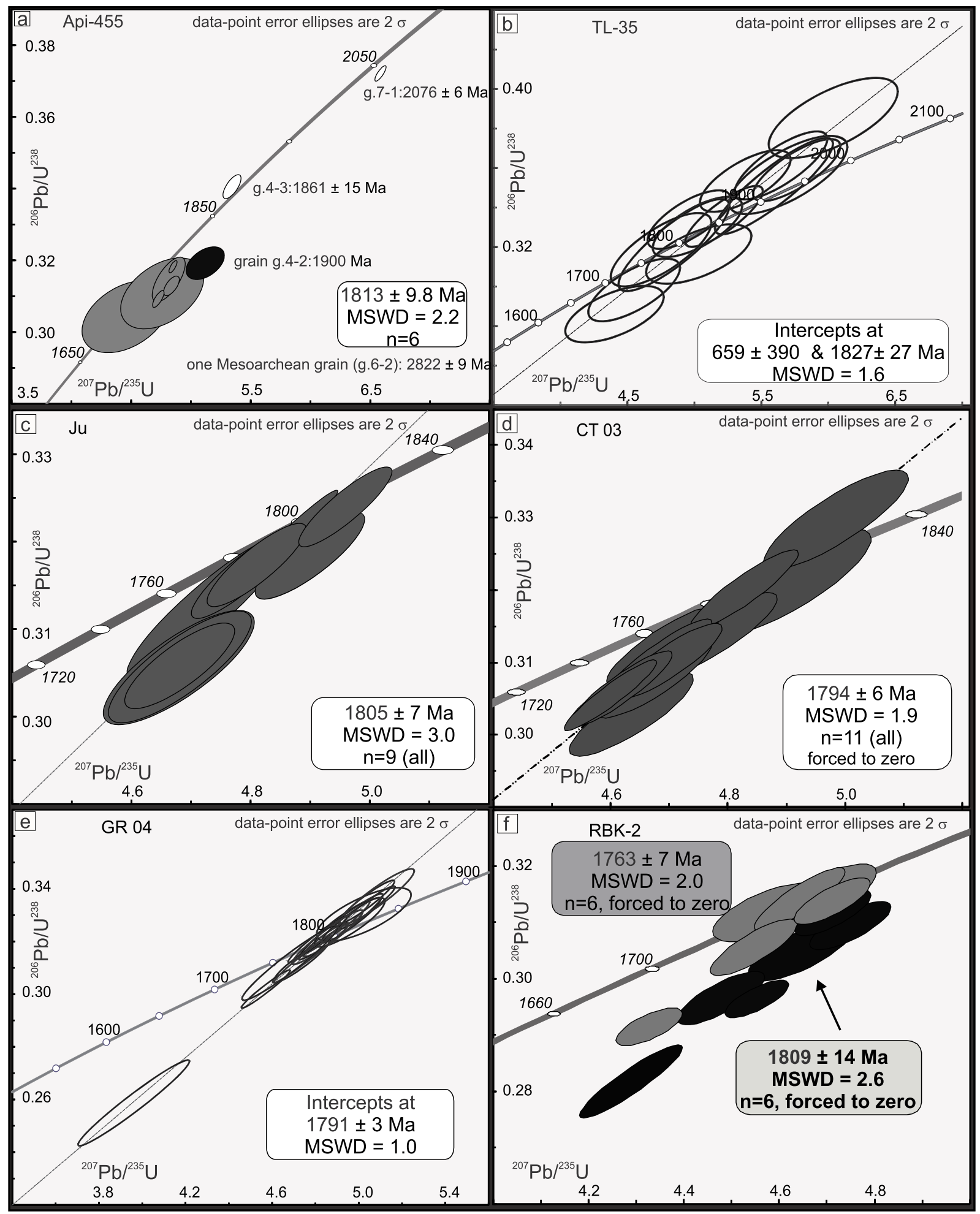

Fig. 3. U-Pb Concordia plots of zircon of granites from WAIB. (a) Paranaíta suite. The age of $1813 \pm 10$ Ma is the crystallization age. The other grains are inherited and yielded ages of Paleoproterozoic to Archean, and (b) The $1827 \pm 27$ Ma age is interpreted as crystallization age; (c) Monzogranite of the São Pedro suite. The age of $1805 \pm 7 \mathrm{Ma}$ is the crystallization age; (d, e and f) U-Pb Concordia plots of zircon of granites from Teles Pires suite.

narrow rims. Some crystals of zircons display U-rich (dark BSE) cores. Radial and cross-cutting fractures occur mostly in the dark gray core of the crystals. Fourteen analyses yield weighted mean ${ }^{207} \mathrm{~Pb} /{ }^{206} \mathrm{~Pb}$ age of $1827 \pm 27 \mathrm{Ma}$ (Fig. $3 \mathrm{~b}$ ) that records the age of crystallization of the granite. One xenocryst core indicates inheritance with ${ }^{207} \mathrm{~Pb} /{ }^{206} \mathrm{~Pb}$ age of 1903 Ma (Table 3 and Fig. 4a).

\subsubsection{Juruena supersuite (São Pedro suite)}

Rocks from this suite are predominantly monzogranite and rarely granodiorite. They show porphyritic texture $(\sim 40-70 \%$ of crystals of Kfeldspar + plagioclase) in phaneritic matrix that consists of quartz, Kfeldspar, plagioclase and biotite. Biotite defines a subtle foliation that surrounds K-feldspar phenocrysts. In general, phenocrysts show deformation in subsolidus conditions, and mafic microgranular enclaves 

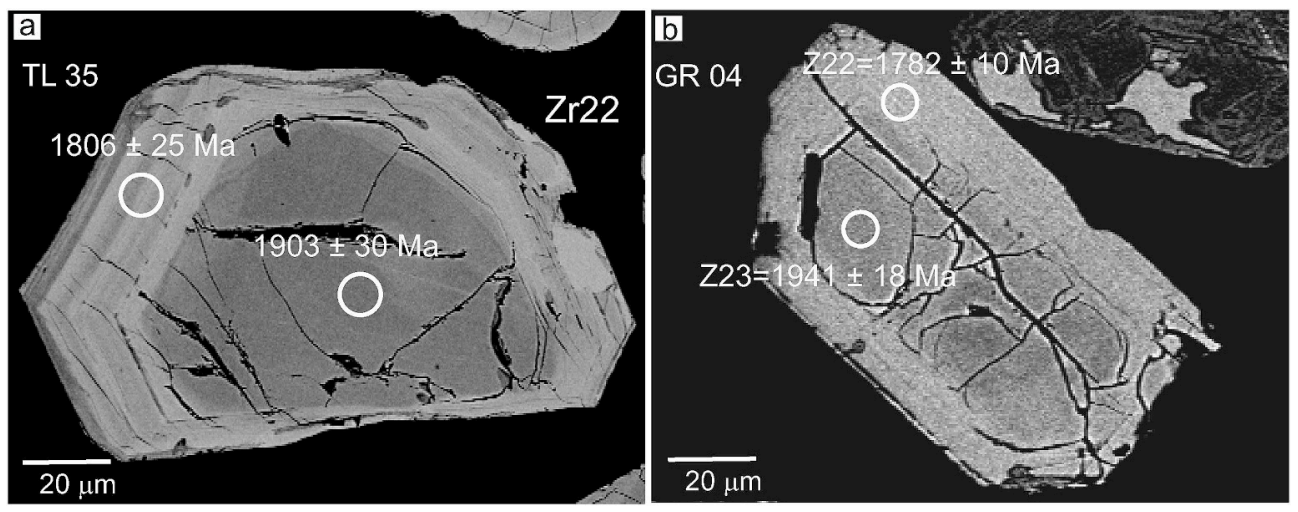

Fig. 4. Backscattered-electron images of zircon grains, illustrating LA-ICP-MS ${ }^{207} \mathrm{~Pb} /{ }^{206} \mathrm{~Pb}$ ages. (a) Grain Zr22 has a core with $1903 \pm 30 \mathrm{Ma}$ and a magmatic rim with $1806 \pm 25 \mathrm{Ma}$. The oldest inherited age is correlated with the Guarantã suite of Peixoto de Azevedo Domain; (b) Grain z23 has magmatic core with $1941 \pm 18 \mathrm{Ma}$ and magmatic rim (z22) with $1782 \pm 10 \mathrm{Ma}$. The oldest inherited age is correlated with the Nhandu suite of Peixoto de Azevedo Domain. White circles indicate LA-ICP-MS analysis position; spot number and age (Ma) shown.

are also common.

Zircons of sample JU (S $10^{\circ} .2252$; W $55^{\circ} .8094$ ) are $>250 \mu \mathrm{m}$ and usually show well-developed euhedral terminations. Isotopic data for age determination were obtained for nine crystals, which yielded an upper intercept age of $1805 \pm 7 \mathrm{Ma}$ (Fig. 3c), interpreted as the crystallization age.

\subsubsection{Teles Pires suite}

The analyzed samples represent different types of granites of the Teles Pires suite, which is divided into two facies: (a) Granitic Leucocratic facies: equigranular leucocratic alkali-feldspar granite and syenogranite, rich in globular quartz, with rapakivi texture; (b) Subvolcanic facies: microsyenogranite, granophyre, quartz-porphyry and quartz-K-feldspar porphyry; highly magnetic, and microporphyritic micromonzonite, with features of mixing of different magmas.

Eleven zircon crystals of porphyritic biotite syenogranite of granitic leucocratic facies (CTO3 - S $9^{\circ} .9230$; W 54 $4^{\circ} .8383$ ) were analyzed and yielded $\mathrm{a}^{207} \mathrm{~Pb} /{ }^{206} \mathrm{~Pb}$ age of $1794 \pm 6 \mathrm{Ma}$, which is interpreted as the crystallization age of the granitic magma (Fig. 3d).

Sample GR 04 (S $10^{\circ} .5367$; W $54^{\circ} .5739$ ) is an isotropic porphyritic syenogranite, produced by shallow crystallization (hypabyssal), and that has an intrusive contact with the volcaniclastic rocks of the Colíder group. This rock has prismatic and subrounded phenocrysts of K-feldspar, in places mantled by plagioclase, and pseudohexagonal to rounded phenocrysts of quartz, in a fine-grained reddish phaneritic matrix, consisting of K-feldspar + quartz + plagioclase and rare biotite. Zircons are euhedral to subhedral (about 150-500 $\mu \mathrm{m}$ long), occasionally translucent, and form a single population. Although some cores are present, most zircons show oscillatory magmatic zoning and, in the majority of cases, there is no discordance at the core-rim boundary. There is, moreover, no significant difference in age between cores and rims of zircons from the syenogranite. Seventeen analyses yielded a weighted mean ${ }^{207} \mathrm{~Pb} /{ }^{206} \mathrm{~Pb}$ age of $1791 \pm 3$ Ma (Fig. 3e) that records the crystallization age of the granite. In addition, two xenocryst populations are recognized: an older represented by one core with minimum ${ }^{207} \mathrm{~Pb} /{ }^{206} \mathrm{~Pb}$ age of $1941 \pm 18 \mathrm{Ma}$ (Fig. 4b) and a younger (zr 07) with $\mathrm{a}^{207} \mathrm{~Pb} /{ }^{206} \mathrm{~Pb}$ age of $1831 \mathrm{Ma}$ (Table 3).

Another granite from this suite, sample $R B K-2$ (S $9^{\circ} .8174$; W $\left.54^{\circ} .9329\right)$ has two main populations of zircons, both magmatic, with $\mathrm{Th} / \mathrm{U}$ ratios ranging from 0.60 to 1.56 (Table 2). The oldest population yielded $\mathrm{a}^{207} \mathrm{~Pb} /{ }^{206} \mathrm{~Pb}(\mathrm{n}=6)$ age of $1809 \pm 14 \mathrm{Ma}$, whereas the youngest population yielded $\mathrm{a}^{207} \mathrm{~Pb} /{ }^{206} \mathrm{~Pb}(\mathrm{n}=6)$ age of $1763 \pm 7 \mathrm{Ma}$ (Fig. 3f). The youngest age is interpreted as the crystallization age of the granite, whereas the oldest age may represent xenocrysts within the alkali-feldspar granite that correspond to country rocks represented by the Paranaíta suite. Additionally, inherited grains (G2-1, G5-3) with ages of 1970 and $2135 \mathrm{Ma}$ (Table 2) suggest inheritance from Nhandu granites and Cuiu-Cuiu basement gneisses, respectively.

\subsubsection{Colíder group}

Rhyolites, rhyodacites, ignimbrites and subordinate andesitic basalts from the Colíder group occur usually associated with the subvolcanic granitic intrusive rocks of the Teles Pires suite, commonly showing textures and structures similar to those of the rhyolites and rhyodacites of the Colíder group. The contacts are transitional and diffuse, wherever visible. Sample $C L D$ (S $10^{\circ} .8285$; W $55^{\circ} .4141$ ) is an amygdaloidal basaltic andesite, in the form of a long dyke trending EW, showing cavities filled with quartz and epidote and, sometimes, obsidian. Amygdules are ellipsoid to elongated, oriented along the igneous flow. In some places, andesitic basalts are overlain by thin layers of ash, with characteristics of surge deposits.

Isotopic analysis of four zircon crystals yielded $\mathrm{a}^{207} \mathrm{~Pb} /{ }^{206} \mathrm{~Pb}$ age of $1785 \pm 25 \mathrm{Ma}$, which is interpreted as the crystallization age of the andesitic basalt. There are also two inherited zircons with age of $1841 \pm 16 \mathrm{Ma}$ (Fig. 5a). This older age (inheritance) represents the granites that crop out at Zé Vermelho mine, to the north of Paranaíta town, and the granites of Acari river, to the SW of Amazonas state (Meloni et al., 2017), probably basement of the volcanic rocks.

Sample $I-688$ (S $10^{\circ} .8351 ; \mathrm{W} 57^{\circ} .4477$ ) is a dark gray andesite, which shows a significant structure of igneous flow with N25E orientation and a network of sub-parallel fractures filled with epidote, quartz and titanite. These rocks are overlain by ignimbrites and volcanogenic sandstones. They have fine-grained phaneritic to aphanitic matrix, consisting of few microphenocrysts of plagioclase and amphibole. Clusters of epidote and white mica developed into the core and microfractures of plagioclase microphenocrysts.

Isotopic analyses of six crystals of zircon yielded $\mathrm{a}^{207} \mathrm{~Pb} /{ }^{206} \mathrm{~Pb}$ age of $1783 \pm 15 \mathrm{Ma}$, which is interpreted as the crystallization age of the andesite. There are also four inherited zircons with age of $1827 \pm 8 \mathrm{Ma}$ (Fig. 5b). The crystallization ages of the two samples of volcanic rocks are identical thus, they have inherited older zircons from magmatic rocks with ages between 1840 and $1827 \mathrm{Ma}$, which are similar to ages obtained in sample $C L D$. Rock outcrops with this age occur in SE Amazonas (Acari river) (Meloni et al., 2017) and in Zé Vermelho deposit (Gomes, 2018).

\subsubsection{5- Vespor Mafic suite}

Ages previously published for rocks of the Vespor Mafic suite include U-Pb (LA-ICPMS) 1773 and 1764 Ma (Ribeiro and Duarte, 2010). In this study, one sample was collected from a porphyritic gabbro, which is intrusive into the gneisses of the basement.

Sample $T L-94$ (S $10^{\circ} .3425$; W $56^{\circ} .1579$ ) is a hornblende gabbro with coarse porphyritic texture, containing prismatic plagioclase crystals measuring up to $2 \mathrm{~cm}$ in diameter, with hornblende filling spaces between plagioclase grains. Hornblende also occurs as porphyroblasts exhibiting sieve texture with quartz inclusions, and partially altered to chlorite.

Fine zoned zircon grains vary from rounded to subhedral prismatic with partly broken terminations and 50-350 $\mu \mathrm{m}$ long. BSE images show 


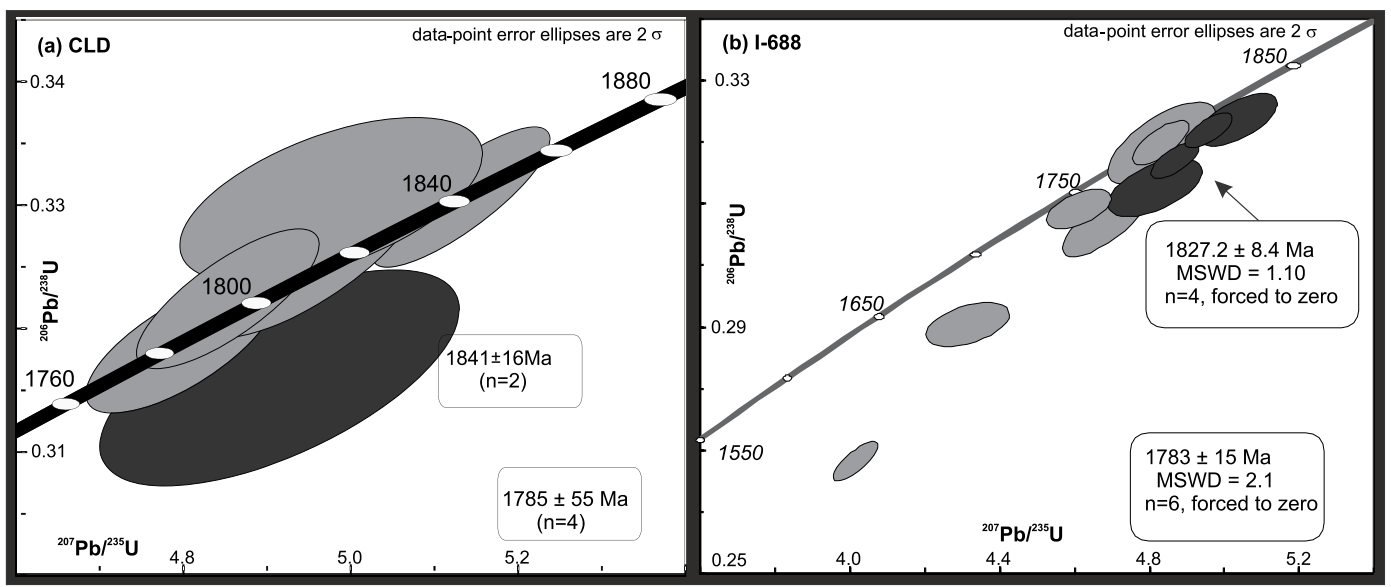

Fig. 5. U-Pb Concordia plots of zircon of volcanic rocks from Colíder group. At (a) and (b) crystallization ages of volcanic rocks. Oldest zircons oldest are 1841-1827 Ma in age.

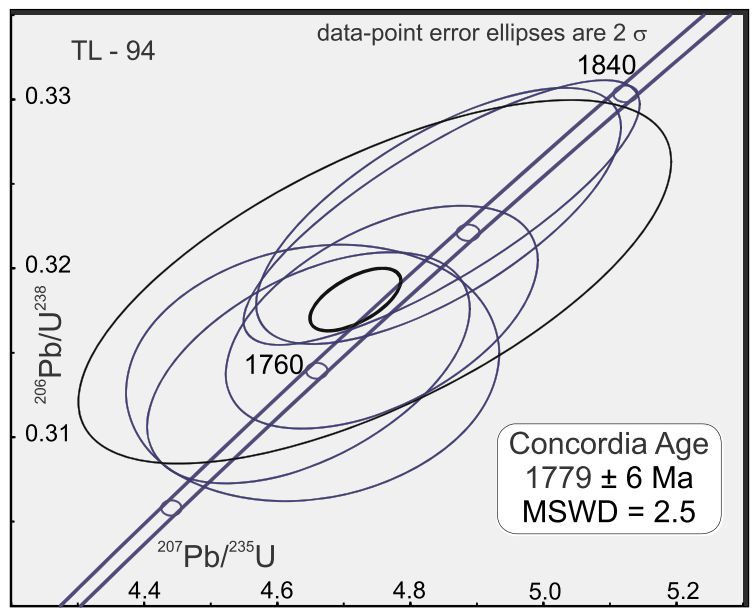

Fig. 6. $\mathrm{U}-\mathrm{Pb}$ Concordia plot of zircon of gabbro from Vespor suite.

that some grains have irregular zoning pattern. The Th/U ratios vary between 0.75 and 1.70, suggestive of magmatic origin. The rock has one population of magmatic zircon and metamorphic rims or older cores not detected. Concordia age is $1779 \pm 6$ Ma (Fig. 6), which represents the age of crystallization of the gabbro.

\subsection{Sm-Nd results}

Data were gathered from 51 samples of previous studies on wholerock Nd isotopes, and the results are shown in Table 4-Appendix B. $\varepsilon_{\mathrm{Nd}(\mathrm{t})}$ was calculated based on crystallization ages from zircon U-Pb dating. For samples without U-Pb ages, $\varepsilon_{\mathrm{Nd}(\mathrm{t})}$ was calculated based on the age obtained for the sample from the same outcrop or for a sample from the same suite. For undated samples, $\varepsilon_{\mathrm{Nd}(\mathrm{t})}$ was calculated for crystallization age of $1.8 \mathrm{Ga}$, which, together with field data, indicates that plutonic and volcanic events are coeval. Model ages of depleted mantle $\left(\mathrm{T}_{\mathrm{DM}}\right)$ were calculated based on the De Paolo model (1981).

Although the studied samples show a wide range of ${ }^{147} \mathrm{Sm} /{ }^{144} \mathrm{Nd}$ ratios, from 0.08 to 0.13 , which is expected due to $\mathrm{SiO}_{2}$ ranging between 63 and $77 \mathrm{wt} \%$, model ages and $\varepsilon_{\mathrm{Nd}(\mathrm{t})}$ have small variations (Fig. 7 and tab. 4-Appendix B).

All samples collected from the granites of the Juruena supersuite, Teles Pires suite and from volcanic rocks of the Colíder group have similar isotopic compositions and $\mathrm{Nd}$ concentration. Granites of the above-mentioned suites have ${ }^{143} \mathrm{Nd} /{ }^{144} \mathrm{Nd}$ initial ratio between 0.510149 and 0.510488 , with $\varepsilon_{\mathrm{Nd}(\mathrm{t})}$ ranging from -3.9 to +2.52 , and

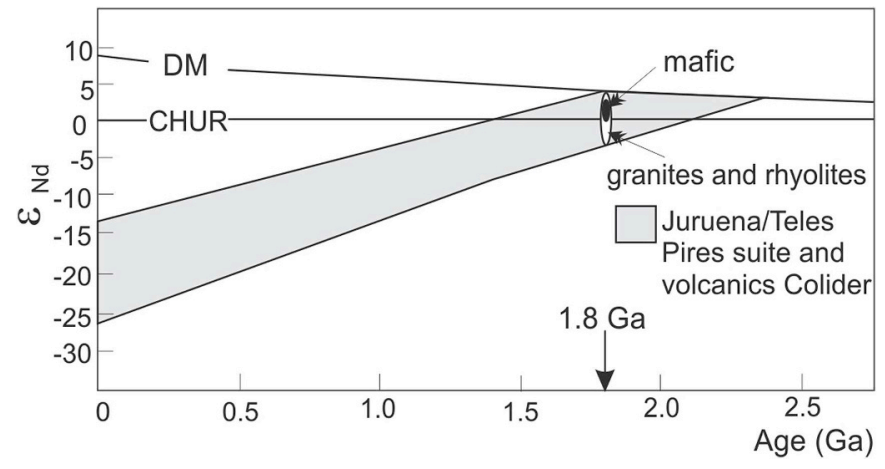

Fig. 7. TDM ages versus $\varepsilon_{\mathrm{Nd}}$ showing fields of isotopic evolution of granites of Juruena supersuite and Teles Pires suite, and volcanic rocks of Colíder group and mafic Vespor suite.

$\mathrm{T}_{\mathrm{DM}}$ model ages ranging from $1.93 \mathrm{Ga}$ to $2.36 \mathrm{Ga}$. Acid volcanic rocks of the Colíder group have ${ }^{143} \mathrm{Nd} /{ }^{144} \mathrm{Nd}$ initial ratios similar to granites, ranging from 0.510144 to 0.510410 , with close-to-zero to slightly negative $\varepsilon_{\mathrm{Nd}(\mathrm{t})}$ values $\left(-0.20\right.$ to -3.71 ), and only one sample has $\varepsilon_{\mathrm{Nd}(\mathrm{t})}$ of +1.26 . $\mathrm{T}_{\mathrm{DM}}$ model ages are similar to granites of Juruena supersuite and Teles Pires suite, ranging from $1.97 \mathrm{Ga}$ to $2.34 \mathrm{Ga}$.

Samples of mafic rocks from the Vespor suite are characterized by slightly higher ${ }^{143} \mathrm{Nd} /{ }^{144} \mathrm{Nd}$ initial ratios, ranging from 0.510327 to 0.510426 , with positive values of $\varepsilon_{\mathrm{Nd}(\mathrm{t})}(+0.31$ to +1.83$)$, and $\mathrm{T}_{\mathrm{DM}}$ model ages between $1.93 \mathrm{Ga}$ and $2.20 \mathrm{Ga}$, which indicate formation from mantle rocks with little participation of crustal material.

$\mathrm{T}_{\mathrm{DM}}$ model ages (2.36 and 1.93) and $\varepsilon_{\mathrm{Nd}}$ values of granitic suites and associated volcanic rocks indicate Paleoproterozoic (Rhyacian/ Orosirian) crustal source (protolith) with partial assimilation of a component of younger mantle source. Mantle participation is consistent with younger model ages (1.93-1.96) and positive $\varepsilon_{\mathrm{Nd}}$ for some samples and, also with some field and petrographic data indicating magma mixing in the studied granite.

An alternative hypothesis for the evolution of the rocks of the western part of the WAIB was proposed by Duarte et al. (2012), who suggested two sources for the origin of the bimodal volcanic-plutonic magmatism. One older source, with $\mathrm{T}_{\mathrm{DM}}$ ages between 2.3 and $2.1 \mathrm{Ga}$, and negative values of $\varepsilon_{\mathrm{Nd}}(\sim-1.5)$, and another younger source, with $\mathrm{T}_{\mathrm{DM}}$ ages between 2.0 and $1.9 \mathrm{Ga}$, and positive values of $\varepsilon_{\mathrm{Nd}}(\sim+1.0)$.

\section{Whole-rock geochemistry}

In this section, granites of the Juruena supersuite, Teles Pires suite, 
and volcanic rocks of the Colíder and Roosevelt groups are compared with the migmatitic rocks of the Nova Monte Verde complex. Chemical data from the Teodósia suite are not interpreted in this study, and the results are available in Costa et al. (2013). Analyzed samples $(n=586)$ are uniformly distributed over the WAIB, results shown in Tables 5, 6 and 7-Appendix C.

a) Juruena supersuite (Paranaíta, São Pedro, Nova Canaã and Zé do Torno suites)

All four suites consist essentially of granites (syenogranite to monzogranite with few alkali-feldspar granites). $\mathrm{SiO}_{2}$ content ranges from 63 to $77 \mathrm{wt} \%$ in the granites, which vary from metaluminous to peraluminous with an increase in $\mathrm{SiO}_{2}$. They show a sub-alkaline trend, which is different from the granites of calc-alkaline series. In contrast, granites plot in the ferrous granite field, and most samples plot in the Atype granite field (Frost et al., 2001). More chemical data, tables and figures are in Appendix C.

\section{b) Teles Pires suite}

In general, granites from the Teles Pires suite have a chemical composition similar to granites of the Juruena supersuite (tab. 5Appendix C). Granites have $\mathrm{SiO}_{2}$ contents from 63 to $78 \mathrm{wt} \%$ and vary from metaluminous to peraluminous as $\mathrm{SiO}_{2}$ content increases. However, in those granites less evolved and with mafic microgranular enclaves, $\mathrm{SiO}_{2}$ contents are lower (63-69 wt\%). They show a sub-alkaline trend, which is different from granites of calc-alkaline series. More chemical data, tables and figures are in Appendix C.

\section{d) Colíder and Roosevelt groups}

Intermediate and acid volcanic rocks from these groups are discussed together because they show similar chemical and mineralogical characteristics (tab. 5). Chemical characteristics of this volcanic set are similar to granites of the Teles Pires suite and Juruena supersuite. Volcanic rocks are predominantly acid, with $\mathrm{SiO}_{2}$ content ranging from 63 to $77 \mathrm{wt} \%$. Rhyolite and rhyodacite predominate, with subordinate dacites and quartz-latites. Rocks are metaluminous to peraluminous and show a strong sub-alkaline trend. More chemical data, tables and figures are in Appendix C.

\section{e) Nova Monte Verde complex}

A genetic link between migmatites and granites has been the subject of discussion and petrological studies by several authors in the world (for example, Sawyer, 1996; Johannes et al., 2003; Johnson et al., 2003). Migmatites, in general, are considered partially melted source rocks of granites (Sawyer, 1998). Moreover, studies have indicated that a considerable part of rocks from the continental crust are the source for the production of significant volumes of granitic magma (Patiño Douce and Johnston, 1991; Clemens and Vielzeuf, 1987). In this context, migmatites from the Nova Monte Verde complex are considered possible sources of the granitoids and volcanic rocks of the Juruena supersuite and Colíder and Roosevelt groups.

Samples from the Nova Monte Verde complex are mostly orthoderived metatexites, with a high proportion of granitic leucosome. Diatexites are subordinate. Chemical analysis of migmatitic gneisses shows a set of rocks that range from tonalite to granite, in addition to rare quartz monzonite. $\mathrm{SiO}_{2}$ contents are variable, ranging from 62 to $74 \mathrm{wt} \%$ and the rocks vary from metaluminous to peraluminous. Chemical data, tables and figures are in Appendix C.

\section{f) Vespor Mafic suite}

Data on major and trace elements of rocks from the Vespor Mafic suite are shown in table 7. In general, mafic rocks have low content of $\mathrm{SiO}_{2}$ (46.30-50.40 wt\%), high contents of $\mathrm{Fe}_{2} \mathrm{O}_{3}(9.37-15.10 \mathrm{wt} \%)$ and $\mathrm{MgO}$ (5.51-12.88 wt\%), low to intermediate content of $\mathrm{TiO}_{2}$ (0.62-1.52 wt\%), and $\mathrm{mg} \#$ values that range from 0.45 to 0.72 . Mafic rocks of the suite are chemically gabbros and show a trend of progressive enrichment in iron with differentiation, which is a diagnostic characteristic of magmas from the tholeiitic series. Complementary chemical data are in Appendix C.

\section{Petrogenesis and tectonic setting}

Mafic rocks from the Vespor suite have low $\mathrm{SiO}_{2}$ contents, and high $\mathrm{TiO}_{2}, \mathrm{Fe}_{2} \mathrm{O}_{3(\mathrm{t})}$ and $\mathrm{MgO}$ contents. They are gabbros in the $\left(\mathrm{K}_{2} \mathrm{O}+\mathrm{Na}_{2} \mathrm{O}\right)$ vs. silica $\left(\mathrm{SiO}_{2}\right)$ diagram and show in the AFM diagram a $\mathrm{FeO}_{\mathrm{t}}$ enrichment trend that is characteristic of tholeiites. These geochemical features indicate that mafic rocks were formed from mantlederived magma, similar to modern P-MORBs and continental tholeiites. The slight enrichment in LREE, positive anomalies of Th, $\mathrm{U}, \mathrm{Ba}, \mathrm{Rb}$ and $\mathrm{Sr}$, and the slight negative anomaly of $\mathrm{Nb}$ are features suggestive of crustal assimilation during magmatic processes (Wilson, 1989). Moreover, trace elements of Vespor mafic rocks are similar to continental tholeiites, particularly enrichment in LREE and negative anomalies of Nb, Zr and Ti (Weaver and Tarney, 1983; Thompson et al., 1984). The negative $\mathrm{Nb}$ anomaly may represent not only the removal of Ti oxides, but also magma contamination by crustal material. These anomalies can also occur in continental tholeiites (for example, Thompson et al., 1984; Dupuy and Dostal, 1984; Cox and Hawkesworth, 1985; Campbell and Griffiths, 1990). Therefore, negative $\mathrm{Nb}$ anomalies are not exclusive of magmas related to subduction. Moreover, a negative HFSE anomaly is not a definitive geochemical characteristic of a subduction zone. In addition, strong enrichment in Th and ETRL is a distinctive feature of continental crust (for examples, Taylor and McLennan, 1985). Therefore, crustal contamination is a mechanism for the development of negative $\mathrm{Nb}$ anomalies in basaltic rocks, not related to a subduction environment.

Isotopic data of mafic rocks indicate close-to-zero values of $\varepsilon_{\mathrm{Nd}}$, which is a common characteristic of modern continental basalts. Therefore, Statherian mafic rocks of the WAIB may have formed by partial melting of a depleted asthenospheric mantle associated with slight assimilation of continental crust in a continental rift environment.

On the other hand, granitic rocks of Juruena supersuite and Teles Pires suite, and the correlated felsic volcanic rocks of Colíder group are characterized by high $\mathrm{SiO}_{2}$ and $\mathrm{K}_{2} \mathrm{O}+\mathrm{Na}_{2} \mathrm{O}$ contents and low $\mathrm{TiO}_{2}$, $\mathrm{Fe}_{2} \mathrm{O}_{3(\mathrm{t})}$ and $\mathrm{MgO}$ contents; most of them classified as granite/rhyolite in geochemical diagrams. They are oxidized ferrous rocks, ranging from alkali-calcic to calc-alkaline. These and other chemical characteristics are similar to A-type granites.

The Vespor suite and Juruena supersuite do not have intermediate petrographic types and, therefore, constitute bimodal magmatism, where the mafic rocks from the Vespor suite and the granites from the Juruena supersuite and Teles Pires suite are two groups with different chemical compositions (Fig. 8).

Intrusive and felsic volcanic rocks can be generated by fractional crystallization of a basaltic magma or by partial melting of old continental crust. The Statherian granitic rocks of the Juruena supersuite and Teles Pires suite and the volcanic rocks of the Colíder group are characterized by close-to-zero values of $\varepsilon_{\mathrm{Nd}(\mathrm{t})}$ (negative and positive) in whole-rock samples, and by model ages (1.97-2.34 Ga) older than crystallization ages $(1.81-1.76 \mathrm{Ga})$. Mafic rocks, in turn, are characterized by slightly positive values of $\varepsilon_{\mathrm{Nd}(\mathrm{t})}$ in whole-rock samples and model ages similar to those of granites $(1.93-2.20 \mathrm{Ga})$. Therefore, Nd isotopic compositions of granites and acid volcanic rocks are similar. This, together with the values of $\varepsilon_{\mathrm{Nd}}$, indicates a mixed source for the Statherian acid magmatism of WAIB. Thus, Statherian plutonic and volcanic felsic rocks may have formed by partial melting of old 


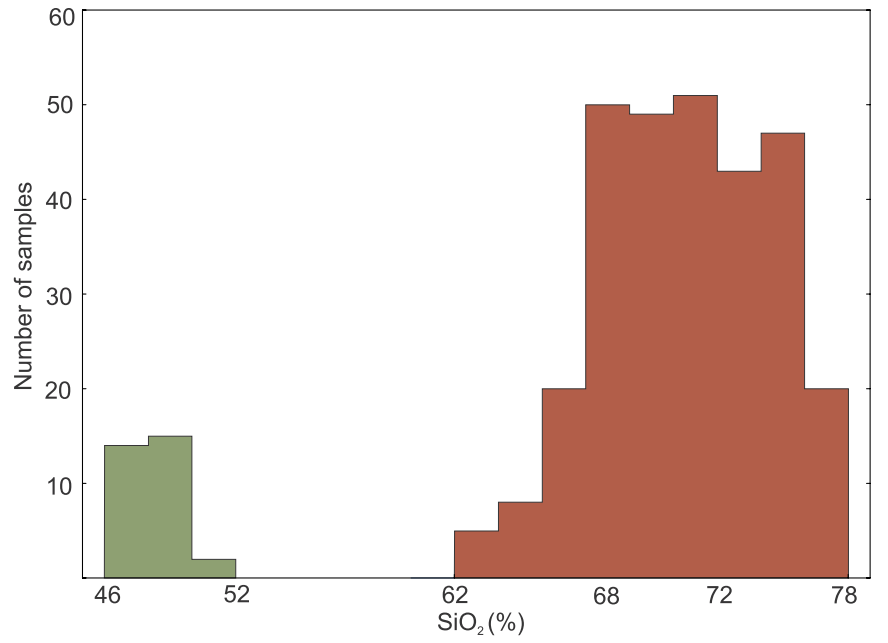

Fig. 8. a) Diagram showing bimodal gabbro-granite assemblage (Vespor suitegreen; Juruena supersuite and Teles Pires suite - red).

continental crust (Ventuari-Tapajós). Anatexis of old crust in the PRNJ was probably induced by ascent of hot asthenospheric mantle during rifting.

Numerical thermal modeling suggests that large-scale crustal melting requires unusually high heat flow (e.g. Petford and Gallagher, 2001; Annen and Sparks, 2002; Dufek and Bergantz, 2005). This applies even in dehydration melting, and the production of relatively dry magmas such as the Juruena supersuite, resulted in the enormous volume of felsic melt required to produce this regionally dominant lithological feature. The suggestion that voluminous mantle-derived magmatism contributed both heat and source material to the petrogenesis of the Juruena supersuite is consistent with recent models for the generation of large-volume felsic magmas in all tectonic environments (e.g. Annen et al., 2006; Bachmann and Bergantz, 2008). Bachmann and Bergantz (2008) argued that evolved felsic magmas form within, and are extracted from, long-lived crystallizing mush zones periodically fed by mantle-derived magmas. Partial melting of crust is considerably less important, but is coupled to emplacement of mush zones, and allows for the transfer of crustal compositional attributes to the interstitial mush magmas. Such models are heavily based on the MASH (melting, assimilation, storage, homogenization; Hildreth and Moorbath, 1988) hypothesis, which attributes large-scale homogeneity in the lower crustal source regions of granites to the formation of MASH domains. These are produced when mantle-derived mafic underplated and intraplated magmas mix with, and assimilate, local crustal components (typically as melts of country rock), producing crystal-rich mush chambers that undergo dynamic homogenization as well as periodic magma recharge (e.g. Hildreth and Moorbath, 1988; Riley et al., 2001; Hildreth and Wilson, 2007).

During this process, magmatism was predominantly bimodal, and mantle rocks interacted with old continental crust (Ventuari-Tapajós crust), resulting in a mixture of mafic-felsic magmas (mush zone; Fig. 9).

In this context, field evidence, together with textures/structures of granites of the studied suites, and an abundance of experimental data from several countries show that microgranular enclaves within granitic plutons and corresponding volcanic rocks were the result of the dynamic interaction between two different types of magmas (Blake et al., 1965; Didier, 1964). This finding, which is widely accepted by most researchers in the field of granites, implies that mafic microgranular enclaves correspond to hot mafic liquids of basic to intermediate composition (45-55\% of $\mathrm{SiO}_{2}$ ), which were injected into colder acid felsic magmas (65-75\% of $\mathrm{SiO}_{2}$ ) (Bonin, 2004). Moreover, abovementioned geochemical data suggest that basaltic and granitic magmas are not comagmatic.
Therefore, the evolutionary history of WAIB in SW Amazonian proto-craton initially consisted of extensional tectonics associated with decompression of upper crust, induced by mantle melting and basaltic magma generation. In this context, the dyke swarm and mafic bodies of Vespor mafic suite were formed. This magma was trapped in the lower crust in the form of subcrustal magmatic layers, providing enough heat for the partial melting and generation of granitic magma (Fig. 9).

At the end of Orosirian and beginning of Statherian, landmasses went through a long process of taphrogenesis, forming bimodal magmatism and sedimentary basins (Brito Neves et al., 1995; Goodwin, 1991; Bossi et al., 1993). Similarly, felsic and mafic magmas ascended to the upper crust through reactivated deep structures, forming mafic bodies and dyke swarms associated with alkali-calcic A-type plutons (gabbros and diabases of the Vespor mafic suite and plutonic/volcanic rocks of the Juruena supersuite and Teles Pires suite, and volcanic rocks of the Colíder group), in addition to fissured acid volcanic rocks. However, during magma rising, mixing took place and the initial composition was changed, generating magmas with intermediate composition and hybrid rocks (for example, andesites and granodiorites).

Therefore, the old continental crust that went through the extensional process consists predominantly of Paleoproterozoic rocks with ages between 2.05 and $1.87 \mathrm{Ga}$, with high k calc-alkaline composition. This old crust is part of the Peixoto de Azevedo Domain of the VentuariTapajós Province. Archean rocks were identified within this domain and are an inlier of old migmatitic rocks. Moreover, further east of the Peixoto de Azevêdo Domain, Archean rocks are more widely distributed (Central Amazonia Province). The Ventuari-Tapajós old crust with Archean fragments was melted by heat-related to basic magma underplating, resulting in significant felsic magmatism, which was widely distributed in the southern part of the Rio Negro-Juruena Province during the beginning of Statherian. Alkali-calcic to calc-alkaline high-K composition characteristic of Paleoproterozoic rocks of the JuruenaTeles Pires-Colíder was inherited from their source - Paleoproterozoic (Archean) rocks of the Ventuari-Tapajós Province (see geochemistry data). Along this hypothesis, model ages of the PRNJ rocks indicate a Paleoproterozoic source (2.0-2.3 Ga), as well as the Orosirian-Archean inherited zircons from the Statherian plutonic-volcanic rocks.

Analysis of the data suggests important and significant participation of crustal sources (Paleoproterozoic/Archean?) in the generation of the predominant acid plutonic volcanism in PRNJ, which took place between 1820 and $1760 \mathrm{Ma}$ and was not related to a subduction environment (Fig. 9).

A model that considers melting of a depleted mantle in an Andean -type arc system to produce long-term felsic magmatism was discussed by Duarte et al. (2012) and Scandolara et al. (2014). However, there is no evidence of tectonic segmentation of an Andean-type arc in the PRNJ during the formation of the WAIB. Geological and geochemical data indicate intra-plate segmentation. According to this reasoning, an ensialic extensional tectonic setting is documented in the PRNJ because of the close association, in time and space, of (Fig. 9): a) granites and felsic volcanic rocks derived from the Ventuari-Tapajós continental crust melting; b) formation of migmatites and granulites coeval to granites/acid volcanic rocks by underplating of basic magma; c) mafic tholeiitic rocks formed by partial melting of the upper mantle, similar to P-MORBs or continental tholeiites; d) mixing of contrasting maficfelsic magmas. Therefore, we propose that the PRNJ records a continental stretching episode, not related to coeval subduction. In addition, evidence of arc-derived magmatism was not found.

\section{Conclusions}

The interpretation of an intraplate setting for Western Amazonia Igneous Belt is based on several lines of evidence, including; 1) lack of evidence for prolonged regional scale compressional deformation; 2) felsic rocks have dominant alkali-calcic, metaluminous to 


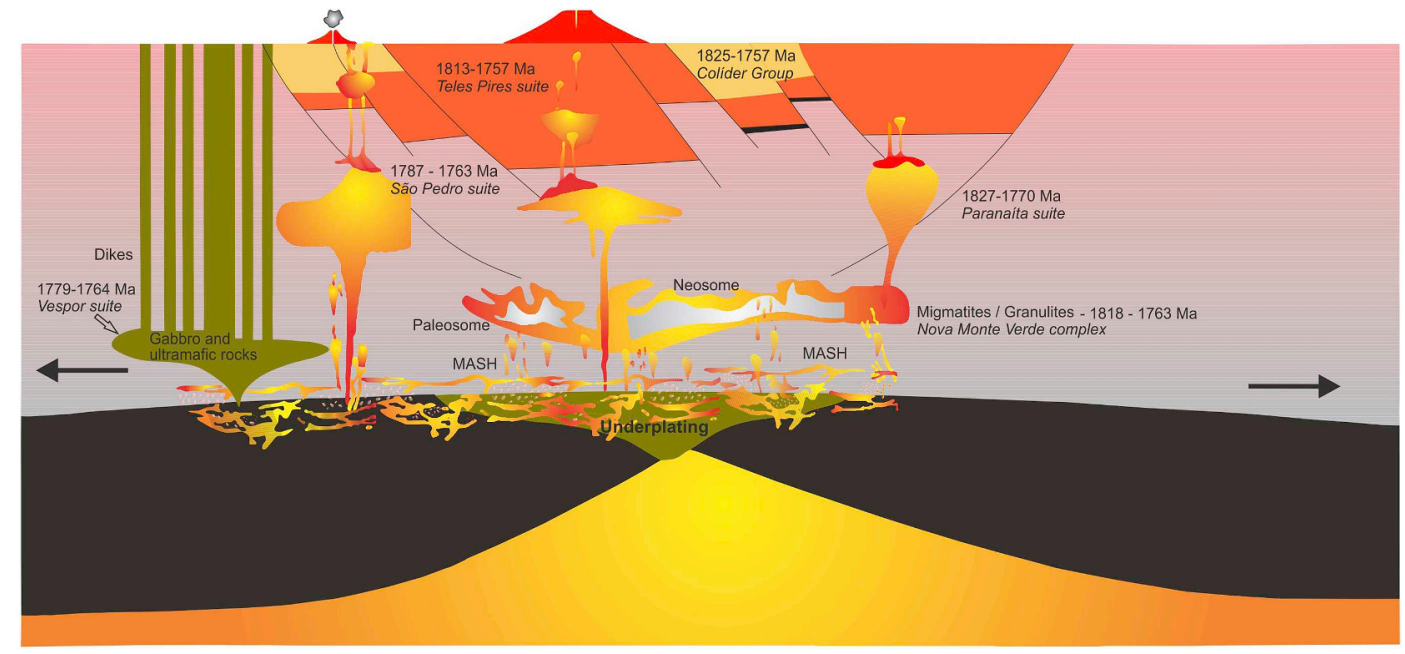

Fig. 9. Schematic model illustrating the relation of magmatic phases of the WAIB, in the southern part of the Rio Negro-Juruena Province, in the Statherian. This is compatible with underplating and ponding of mantle-derived magmas beneath thinned Ventuari-Tapajós lithosphere, initiating high-grade metamorphism and anatexis of the overlying crust.

peraluminous, ferrous, geochemical characteristics similar to A-type granites (Juruena supersuite, Teles Pires suite and Colíder group); 3) quasi-absence of intermediate rocks and predominance of bimodal (basic-acid) magmatism; and 4) presence of inherited zircons 1.87 to $2.05 \mathrm{Ga}$, as well as Archean ages in the granitic and volcanic rocks belonging to WAIB, are also suggestive of derivation from melting of pre-existing crustal basement (Ventuari-Tapajós Province).

The erupted magmas formed volcanoes and lava flows, volcanic domes and tuff plateaus above plutonic A-type granites, and were subsequently eroded. Silicic members are represented by granites and rhyolitic-rhyodacitic volcanic rocks, mafic members by gabbroic rocks and diabase dykes. Intermediate rocks are rare. Local magma mingling and hybridization occurred in several areas. This geologic framework explains the origin of the alkali-calcic granite magmas, bimodal character of magmatism, thinning of lower crust, and extensional setting. In addition, this volcano-plutonic magmatism can be related to silicicdominated igneous province (Silicic Large Igneous Province-SLIP) in terms of areal extent, eruptive volume and petrogenetic characteristics.

The whole assemblage of basic and silicic rocks of WAIB was formed between c. 1825 and 1757 Ma. Magmatic activity happened in several and intermittent pulses during $60 \mathrm{My}$. After c. 1770 Ma magmatic activity within the WAIB gradually ceased. The latest stages of WAIB evolution (1763-1757 Ma) were the formation of minor intrusions of late subalkaline/subvolcanic granites and volcanic-sedimentary sequence (Zé do Torno and Teodósia suites and Roosevelt group, respectively).

$\mathrm{Nd}$ whole-rock isotope compositions suggest a prevailingly intermediate-felsic crustal source for parental magma of granites with some input of juvenile $\mathrm{Nd}$ from coeval mantle-derived tholeiite melts. Associated mafic rocks of all regions have Nd isotope signatures largely overlapping those of associated granites.

The preferred model of formation of WAIB envisages the emplacement of large volumes of hot mantle-derived melts into the lower crust. These processes resulted in partial melting of lower-crustal material, mixing with mantle-derived melts and formation of granitic melts. Emplacement of tholeiitic melts into the middle crust and partial crystallization caused extensive melting of ambient crust and formation of the whole spectrum of granitic rocks present in WAIB. Magmatic underplating with voluminous dehydration partial melting of deep crust is the most plausible mechanism for the bimodal magmatic association in the PRNJ. Felsic rocks are essentially crust derived, but have a mantle component, and evolved through assimilation, hybridization, and fractional crystallization. The observed mantle component in the granites was related to mixing of mantle-derived mafic magmas and crust-derived felsic magmas.

\section{Acknowledgements}

This paper is an outcome of research in the Juruena-Teles Pires project, undertaken by the Geological Survey of Brazil - CPRM. Constructive reviews of this manuscript by an anonymous reviewer are gratefully acknowledged. We also thank Gabriel Dutra de Lima for help with English writing.

\section{Appendix A. Supplementary data}

Supplementary data to this article can be found online at https:// doi.org/10.1016/j.jsames.2019.102326.

\section{References}

Rapakivi granites and related rocks in central Sweden. Ahl, M., Andersson, U.B., Lundqvist, T., Sundblad, K. (Eds.), SGU Ca 87, 99.

Aitken, A.R.A., Raimondo, T., Capitanio, F.A., 2013. The intraplate character of supercontinent tectonics. Gondwana Res. 24, 807-814.

Anderson, J.L., 1983. Proterozoic anorogenic granite plutonism of the North America. In: In: Medaris, L.G., Mickelson, D.M., Byers, C.W., Shanks, W.C. (Eds.), Proterozoic Geology, vol. 161. Memoir-Geological Society of America, pp. 133-154.

Anderson, J.L., Bender, E.E., 1989. Nature and origin of Proterozoic A-type granitic magmatism in the southwestern United States of America. Lithos 23, 19-52.

Annen, C., Sparks, R.S.J., 2002. Effects of repetitive emplacement of basaltic intrusions on thermal evolution and melt generation in the crust. Earth Planet. Sci. Lett. 203, 937-955.

Annen, C., Blundy, J., Sparks, R.S.J., 2006. The genesis of intermediate and silicic magmas in deep crustal hot zone. J. Petrol. 47, 505-539.

Assis, R.R., 2015. Depósitos Auríferos Associados ao Magmatismo Félsico da Província de alta Floresta (MT), Cratón Amazônico: Litogeoquímica, Idade das mineralizações e Fonte dos Fluidos. Tese de Doutorado, Universidade de Campinas, pp. 326p (in Portuguese).

Bachmann, O., Bergantz, G.W., 2008. Rhyolites and their source mushes across tectonic settings. J. Petrol. 49, 2277-2285.

Barnes, M.A., Rohs, C.R., Anthony, E.Y., Van Schmus, W.R., Denison, R.E., 1999. Isotopic and elemental chemistry of subsurface Precambrian igneous rocks, west Texas and eastern New Mexico. Rocky Mt. Geol. 34, 245-262.

Barros, M.A.S., Chemale Jr., F., Nardi, L.V.S., Lima, E.F., 2009. Paleoproterozoic bimodal post-collisional magmatism in the southwestern Amazonian Craton, Mato Grosso, Brazil: geochemistry and isotopic evidence. J. South Am. Earth Sci. 27, 11-23.

Barros, M.A.S., Barros, A.J.P., Santos, J.O.S., Rocha, M.L.B.P., 2015. Extension of the Tapajós domains to the alta floresta gold province: evidence from U-Pb shrimp ages of the Nhandu intrusive suite at 1962 and 1967 Ma. In: 14 Simpósio de Geologia da Amazônia, (in Portuguese).

Biondi, J.C., Santos, R.V., Cury, L.F., 2013. The paleoproterozoic Aripuanã Zn-Pb-Ag (Au, $\mathrm{Cu}$ volcanogenic massive sulfide deposit, mato Grosso, Brazil: geology, geochemistry of alteration, carbon and oxygen isotope modeling, and implications for genesis. Econ. Geol. 108, 781-811. 
Blake, D.H., Elwell, R.W.D., Gibson, I.L., Skelhorn, R.R., Walker, G.P.L., 1965. Some relationships resulting from the intimate association of acid and basic magmas. J. Geol. Soc. London 121, 31-49.

Bonin, B., 2004. Do coeval mafic and felsic magmas in post-collisional to within-plate regimes necessarily imply two contrasting, mantle and crustal, sources? A review. Lithos 78, 1-24.

Bonin, B., 2007. A-type granites and related rocks: evolution of a concept, problems and prospects. Lithos 97, 1-29.

Bossi, J., Campal, N., Civeta, L., Demarchi, G., Girardi, V.A.V., Mazzucchelli, M., Negrini, L., Rivalenti, G., Fragoso César, A.R.S., Sinigoi, S., Teixeira, W., Piccirillo, E.M., Molesini, M., 1993. Early proterozoic dike swarms from western Uruguay: geochemistry, Sr-Nd isotopes and petrogenesis. Chem. Geol. 106, 263-277.

Botelho, N.F., Moura, M.A., 1998. Granite-ore deposit relationships in Central Brazil. J. South Am. Earth Sci. 1, 427-438.

Brito Neves, B.B., Sá, J.M., Nilson, A.A., Botelho, N.F., 1995. A Tafrogênese Estateriana nos blocos Paleoproterozóicos da América do Sul e processos subseqüentes. Geonomos 3, 1-21 (in Portuguese).

Campbell, I.H., Griffiths, R., 1990. Implications of mantle plume structure for the evolution of flood basalts. Earth Planet. Sci. Lett. 99, 79-93.

Clemens, J.D., Vielzeuf, D., 1987. Constraints on melting and magma production in the crust. Earth Planet. Sci. Lett. 86, 287-306.

Costa, U.A.P., Oliveira, A.C.S., Betiolo, L.M., Splendor, F., Bahia, R.B., Almeida, M.E., Reis, N., 2013. Carta Geológica: Folha Sumauma - SB.20-Z-D. Companhia de Pesquisas de Recursos Minerais-CPRM, Manaus (in Portuguese).

Cox, K.G., Hawkesworth, C.J., 1985. Geochemical stratigraphy of the Deccan Traps at Mahabaleshwar, Western Ghats, India, with implications for open system magmatic processes. J. Petrol. 26, 355-387.

Dall'Agnol, R., Oliveira, D.C., 2007. Oxidized, magnetite-series, rapakivi-type granites of Carajas, Brazil: implications for classification and petrogenesis of A-type granites. Lithos 93, 215-233.

Dall'Agnol, R., Lafon, J.M., Macambira, M.J.B., 1994. Proterozoic anorogenic magmatism in the Central Amazonian province: geochronological, petrological and geochemical aspects. Mineral. Petrol. 50, 113-138.

Dall'Agnol, R., Teixeira, N.P., Rämö, O.T., Moura, C.A.V., Macambira, M.J.B., Oliveira, D.C., 2005. Petrogenesis of the paleoproterozoic, rapakivi, A-type granites of the archean carajás metallogenic province, Brazil. Lithos 80, 101-129.

De Paolo, D.J., 1981. Trace element and isotopic effects of combined wallrock assimilation and fractional crystallization. Earth Planet. Sci. Lett. 53, 189-202.

Didier, J., 1964. Etude pétrographique des enclaves de quelques granites du Massif Central français. Ann. Fac. Sci. Univ. Clermont-Gerrand 23, 254-pp.

Duarte, B.T., Rodrigues, B.J., Riveiro, E.P.S., Scandolara, J.E., 2012. Tectonic evolution of the Juruena magmatic arc between the Aripuanã and Juruena rivers: northwest mato Grosso state, Brazil. Rev. Bras. Geociencias 42, 824-840.

Dufek, J., Bergantz, G.W., 2005. Transient two-dimensional dynamics in the upper conduit of a rhyolitic eruption: a comparison of closure models for the granular stress. J. Volcanol. Geotherm. Res. 143, 113-132.

Dupuy, C., Dostal, J., 1984. Trace element geochemistry of some continental tholeiites. Earth Planet. Sci. Lett. 67, 61-69.

Emslie, R.F., 1991. Granitoids of rapakivi granite-anorthosite and related associations. Precambrian Res. 51, 173-192.

Frost, B.R., Frost, C.D., 2008. A geochemical classification for feldspathic igneous rocks. J. Petrol. 49, 1955-1969.

Frost, B.R., Barnes, C.G., Collins, W.J., Arculus, R.J., Ellis, D.J., Frost, C.D., 2001. A geochemical classification for granitic rocks. J. Petrol. 42, 2033-2048.

Gomes, V.S., 2018. Idades U-Pb e Isótopos Lu-Hf em zircão usando LA-ICP-MS nas rochas do arcabouço geológico do depósito de ouro Zé Vermelho, porção centro-norte da Província Aurífera Alta Floresta: implicações tectônicas e metalogenéticas. Dissertação (mestrado) - Universidade Federal de Mato Grosso, Instituto de Ciências Exatas e da Terra (in Portuguese).

Goodwin, A.M., 1991. Precambrian Geology. The Dynamic Evolution of the Continental Crust, vol. 129. Academic Press. Geological Magazine, London, San Diego, New York, Berkeley, Boston, Sydney, Tokyo, Toronto, pp. 66605.

Haapala, I., 1985. Memorial of thure Georg Sahama. Am. Mineral. 70, 433-435.

Haapala, I., Rämö, O.T., 1999. Rapakivi granites and related rocks: an introduction. Precambrian Res. 95, 1-7.

Hildreth, W., Moorbath, S., 1988. Crustal contributions to arc magmatism in the Andes of Central Chile. Contrib. Mineral. Petrol. 98, 455-489.

Hildreth, W., Wilson, C.J.N., 2007. Compositional zoning of the BishopTuff. J. Petrol. 48, 951-999.

Japan International Cooperation Agency (JICA), Metal Mining Agency of Japan (MMAJ), 2001. Report on the Mineral Exploration in the Alta Floresta Area, Federative Republic of Brazil: Phase III. JICA; MMAJ, Tokyo.

Johannes, W., Ehlers, C., Kriegsman, L.M., Mengel, K., 2003. The link between migmatitesand S-type granites in the Turku area, southern Finland. Lithos 68, 69-90.

Johnson, T.E., Hudson, N.F.C., Droop, G.T.R., 2003. Evidence for a genetic granite-migmatite link in the Dalradian of NE Scotland. J. Geol. Soc. 160, 447-457.

Leite, J.A.D., Sousa, M.Z.A., Saes, G.S., Macambira, M.J.B., Xavier, R.P., Siqueira, A.J., Batata, M.E.F., Oliveira, F.A., Silva Jr., J.G., Quadros, A.P., 2005. Caracterização do depósito polimetálico ( $\mathrm{Zn}, \mathrm{Pb}, \mathrm{Ag}, \mathrm{Cu}-\mathrm{Au}$ ) de Aripuanã, mato Grosso. In: Marini, O.J., Queiroz, E.T., Ramos, W.B. (Eds.), Caracterização de Depósitos Minerais em Distritos Mineiros da Amazônia. Brasília, DNPM-CT-Mineral/FINEP-ADIMB, pp. 601-686 (in Portuguese).

Meloni, R.E., Benevides Filho, P.R., Lisboa, T., Simões, M.S., Ramos, M.N., Queiroz, L.C., 2017. Mapa Geológico-Geofísico: ARIM Sudeste Do Amazonas. Manaus: CPRM (in Portuguese).

Neder, R.D., Leite, J.A.D., Figueiredo, B.R., McNaugton, N.J., 2002. 1.76 Ga volcanoplutonism in the southwestern Amazonian Craton, Aripuanã-MT, Brazil: tectonostratigraphic implications from SHRIMP U-Pb zircon data and rock geochemistry. Precambrian Res. 119, 171-187.
Nurmi, P.A., Haapala, I., 1986. The Proterozoic granitoids of Finland: granite types, metallogeny and relation to crustal evolution. Bull. Geol. Soc. Finl. 58, 203-233.

Paes de Barros, A.J., 2007. Granitos da região de Peixoto de Azevedo - Novo Mundo e mineralizações auríferas relacionadas - Província Aurífera Alta Floresta (MT). Tese de Doutorado, Instituto de Geociências, Universidade Estadual de Campinas, Campinas, pp. 154p (in Portuguese).

Patiño Douce, A.E., Johnston, A.D., 1991. Phase equilibria and melt productivity in the pelitic system: implications for the origin of peraluminous granitoids and aluminous granulites. Contrib. Mineral. Petrol. 107, 202-218.

Petford, N., Gallagher, K., 2001. Partial melting of mafic (amphibolitic) lower crust by periodic influx of basaltic magma. Earth Planet. Sci. Lett. 193, 483-489.

Pinho, M.S.A.B., Pinho, F.E.C., Quadros, A.P., Chemale, F., 2001. Discussão do termo uatumã-iriri, região norte do Estado de Mato Grosso-Brasil. In: Resumos Expandidos.VII Simpósio de Geologia da Amazonia, Sociedade Brasileira de Geologia, Belém, pp. 15-18 (in Portuguese).

Pirajno, F., Santosh, M., 2015. Mantle plumes, supercontinents, intracontinental rifting and mineral systems. Precambrian Res. 259, 243-261.

Rämö, O.T., Haapala, I., 1995. One hundred years of rapakivi granite. Mineral. Petrol. 52, 129-185.

Reis, N.J., Teixeira, W., Hamilton, M.A., Bispo-Santos, F., Almeida, M.A., D'Agrella-Filho, M.S., 2013. Avanavero mafic magmatism, a late Paleoproterozoic LIP in the Guiana Shield, Amazonian Craton: U-Pb ID-TIMS baddeleyite, geochemical and paleomagnetic evidence. Lithos 174, 175-195.

Ribeiro, P.S.E., Duarte, T.B., 2010. Geologia e Recursos Minerais das Folhas Rio Guariba e Rio Aripuanã. Projeto Noroeste-Nordeste de Mato Grosso; Programa Geologia do Brasil (PGB). CPRM, Goiânia, pp. 248 escala 1:250.000 (in Portuguese).

Riley, T.R., Leat, P.T., Pankhurst, R.J., Harris, C., 2001. Origin of large volume of rhyolitic volcanism in the Antarctic Peninsula and Patagonia by crustal melting. J. Petrol. 42, 1043-1065.

Rizzotto, G.J., Quadros, M.L., 2005. Geologia do sudoeste do Craton Amazônico. In: In: Horbe, A.M.C., Souza, V. da S. (Eds.), Contribuições à Geologia da Amazônia. Belém, vol. 4. SBG-Núcleo Norte, pp. 69-84 (in Portuguese).

Rizzotto, G.J., Ladeira, C.A., Rios, F.S., Duarte, T.B., Lopes, L.B., Gonçalves, G.F., Netto, G.B., Fuentes, D.B.V., Oliveira, A.C., Lisboa, T., 2016. Significado Tectônico das rochas de alto grau do norte do Mato Grosso. In: Congresso Brasileiro de Geologia, 48, Porto Alegre - RS. Anais. Sociedade Brasileira de Geologia, (in Portuguese).

Rizzotto, G.J., Alves, C.L., Rios, F.S., Barros, M.A.S., 2019. The Nova Monte Verde metamorphic core complex: tectonic implications for the southern Amazonian craton. J. South Am. Earth Sci. 91, 154-172.

Santos, J.O.S., Hartmann, L.A., Gaudette, H.E., Groves, D.I., McNaughton, N.J., Fletcher, I., 2000. A new understanding of the provinces of the Amazonian craton based on integration of field mapping and U-Pb and Sm-Nd geochronology. Gondwana Res. 3, 453-488.

Santos, F.S., Pierosan, R., Barros, M.A.S., Geraldes, M.C., Lima, M.F., 2019. Petrology of the Colíder group volcanic successions in the northernmost Mato Grosso, Brazil: a contribution to the knowledge of the felsic volcanism of the Alta Floresta Gold Province. J. South Am. Earth Sci. 89, 10-29.

Sawyer, E.W., 1996. Melt-segregation and magma flow in migmatites:implications for the generation of granite magmas. Trans. R. Soc. Edinb. Earth Sci. 87, 85-94.

Sawyer, E.W., 1998. Formation and evolution of granite magmas during crustal reworking: the significance of diatexites. J. Petrol. 39, 1147-1167.

Scandolara, J.E., Ribeiro, P.S.E., Frasca, A.A.S., Fuck, R.A., Rodrigues, J.B., 2014. Geochemistry and geochronology of mafic rocks from the Vespor suite in the Juruena arc, Roosevelt-Juruena terrane, Brazil: implications for Proterozoic crustal growth and geodynamic setting of the SW Amazonian craton. J. South Am. Earth Sci. 53, 20-49.

Scandolara, J.E., Correa, R.T., Fuck, R.A., Souza, V.S., Rodrigues, J.B., Ribeiro, P.S.E. Frasca, A.A.S., Saboia, A.M., Lacerda Filho, J.V., 2017. Paleo-Mesoproterozoic arcaccretion along the southwestern margin of the Amazonian craton: the Juruena accretionary orogen and possible implications for Columbia supercontinent. J. South Am. Earth Sci. 73, 223-247.

Silva, M.G., Abram, M.B., 2008. Projeto Metalogenia da Província Aurífera Juruena-Teles Pires, Mato Grosso. Informe de Recursos Minerais, vol. 16. CPRM-Goiânia, pp. 212p (in Portuguese).

Silva, G.H., Leal, J.W.L., Montalvão, R.M.G., 1974. Esboço geológico de parte da Folha SC.21-Juruena. In: Congresso Brasileiro de Geologia, 28, Porto Alegre (RS), vol. 4 SBG - Sociedade Brasileira de Geologia, pp. 309-320 (in Portuguese).

Souza, J.O., Frasca, A.A.S., Oliveira, C.C., 2005. Projeto. Província Mineral de Alta Floresta. Geologia e Recursos Minerais das folhas Rio São João da Barra (SC.21- V-D), Alta Floresta (SC.21-X-C), Ilha 24 de Maio (SC.21-Z-A), Vila Guarita (SC.21- Z-B), estados de Mato Grosso e Pará. Escala 1:250.000. CPRM, Brasília (in Portuguese).

Storey, B.C., Leat, P.T., Ferris, J.K., 2001. The location of mantle-plume centers during the initial stages of Gondwana breakup. Geol. Soc. Am. Spec. Pap. 352, 71-80.

Tassinari, C.C.G., Macambira, M.J.B., 1999. Geochronological provinces of the amazonian craton. Episodes 22, 174-182.

Taylor, S.R., McLennan, S.M., 1985. The Continental Crust: its Composition and Evolution. Blackwell, Scientific Publication, Carlton, pp. 312.

Thompson, R.N., Morrison, M.A., Henry, G.L., Parry, S.J., 1984. An assessment of the relative roles of crust and mantle in magma genesis: an elemental approach. Phil. Trans. R. Soc. A 310, 549-590.

Turcotte, D.L., Schubert, G., 2002. Geodynamics, second ed. Cambridge, New York, Melbourne, pp. 456.

Weaver, B.L., Tarney, J., 1983. In: Hawkesworth, C.J., Norry, M.J. (Eds.), Continental Flood Basalts, Chemistry of the Sub-continental Mantle: Inferences from Archaean and Proterozoic Dykes and Continental Flood Basalts. Shiva Publications, Nantwich) Cheshire, pp. 209-290.

Wilson, M., 1989. Igneous Petrogenesis. A Global Tectonic Approach. Unwin Hyman, London, Boston, Sydney, Wellington, pp. 466. 